\section{The Moral Paradox of Peace and War}

Conway Memorial Lecture delivered at Conway Hall, Red Lion Square, W.C.1, on March 23, 1941. By Prof. J. C. Flugel. Pp. xi + 52. (London : Watts and Co., Ltd., 1941.) Paper, 1s. net; cloth, 2s. net. TN his highly suggestive and constructive Conway Memorial Lecture, "The Moral Paradox of Peace and War", Prof. J. C. Flugel gives us an acute analysis which is as pertinent to our plans for reconstruction as to the building of a world order from which war has been eliminated. Starting with an analysis of the moral qualities which are responsible for the real challenge of war and which have already led to a certain recognition of the need for a moral equivalent of war, he indicates concisely the points at which this challenge must be met in a progressive society in which full expression is given to legitimate desires and aspirations. Notably he stresses the spirit of adventure, with all it connotes of excitement, uncertainty, danger and tenseness or strenuous endeavour. Of this, as well as the social solidarity, the heightened sense of the individual being needed, and the identification with a nobler cause for which he or she is prepared to make any sacrifice, any stable order must take account of, and must seek to satisfy by discovering, a common purpose comparable in intensity with that induced by war. The great task that confronts democracy is to find a formula for integration in harmony with its own essential spirit, which will express our fundamental agreement as to the ultimate goal while preserving our present liberty of thought and discussion as to the best means of attaining this goal. As Prof. Flugel sees it-and in this most scientific workers will concur-we must learn to face the stark realities of man's place in Nature, and find in the challenge and opportunity they afford for the exercise of human genius, combativeness, courage and co-operation, the true moral equivalent of war.

R. B.

\section{Aids to Inorganic Chemistry}

By R. G. Austin. Pp. $x+348$. (London : Baillière, Tindall and Cox, 1940.) $5 s$.

THIS small volume is not intended as a complete text-book of inorganic chemistry, but is designed to give students, who have already attended lectures on the subject, a condensed survey of the principal facts. The subject-matter covers the course required by students of pharmacy, medicine, dental and veterinary surgery.

The preliminary chapters are rightly devoted to general topics such as the atomic theory, acids, bases, salts and the periodic classification. Unlike the nonmetals, the metals are considered in the same sequence as they occur in the periodic table, and this has enabled the author to stress their family relationships. The medical aspects of chemistry have been emphasized. wherever possible, and the reader will find the notes on the physiological action of common inorganic substances both interesting and profitable.

The author states in the preface that "simple interpretations of the mechanism of chemical reactions have been given prominence in order that students may gain some insight into the principles of chemical change" ; it is therefore surprising to find that the ionic aspect of inorganic reactions has been almost totally neglected. In spite of this omission, students of medicine and allied subjects, in search of a book containing a wealth of concise factual matter, should find the book a useful aid to their studies.

This Living World

A. C. C.

A College Course in Science. By Prof. C. C. Clark and R. H. Hall. Pp. $x+519$. (New York and London : McGraw-Hill Book Co., Inc., 1940.) 22s. 6d.

7 HIS well-written and well-illustrated book can 1 be recommended especially to those teachers in training who expect to teach general biology in primary or secondary schools. It displays an unusually expanded breadth of vision, thus covering all aspects of life and living. Though the book will not satisfy the needs of the student of biology, from the point of view of examinations, it would well form a supplement to his more academic reading.

In a form which combines accuracy with pleasant reading, the book presents the gist of modern knowledge about the living world, with special reference to the physical development of man and the structure and functioning of his body. Thus it is of cultural as well as simply academic value.

\section{Radioactivité et transmutation des atomes}

Par Dr Théodore Kahan. (Collection Armand Colin : Section de physique, No. 222.) Pp. 224. (Paris : Armand Colin, 1940.) 15 francs.

R. KAHAN'S stimulating account of the more recent developments in radioactivity and the artificial transmutation of the elements will be welcomed by all students who require a short up-todate survey of the subject. It gives a very satisfactory account of the state of our knowledge of $\alpha$-, $\beta$ - and $\gamma$-ray spectra which is easily followed, and also gives a discussion of the energeties of nuclear changes which is particularly clear and helpful. His treatment of nuclear reactions such as $(\alpha, p),(\alpha, n)$, etc. covers all the more important aspects in a remarkably concise way. The reviewer hopes that this little volume may still be obtainable in Great Britain.

L. F. B.

The Study of the Soil in the Field

By G. R. Clarke. Third edition. Pp. 228. (London : Oxford University Press, 1941.) 6s. 6d. net.

7 HE third edition of this valuable little handbook of soil survey differs from the second edition only in having an appendix in the form of the instructions to surveyors, accepted by the Soil Survey Conference of Great Britain. This should add considerably to its practical utility. The author states that the time is inappropriate for a revision of the text; nevertheless it is to be regretted that, since the book is apparently (and deservedly) becoming a standard work on soil survey, the opportunity was not taken to remedy some inconsistencies in literary composition and the misuse of abbreviations which have been freely invented by the author and employed often without explanation, leaving their meaning to be guessed by the reader. 